\title{
New state record of four species of gall midges (Insecta, Diptera, Cecidomyiidae)
}

\author{
Valéria Cid Maia \\ Museu Nacional, Departamento de Entomologia, 20.940-040 Rio de Janeiro, RJ, Brazil. \\ E-mail: maiavcid@acd.ufrj.br
}

\begin{abstract}
Four gall midge species (Insecta, Diptera, Cecidomyiidae), Bruggmannia acaudata, B. elongata, B. robusta, and Pisphondylia brasiliensis, are recorded for the first time in the State of Bahia. All of them induce galls on Guapira opposita (Nyctaginaceae), the first three in leaves and the fourth in buds.
\end{abstract}

Insect galls inventories have been developed in Brazil, mainly in areas of Minas Gerais, Rio de Janeiro and São Paulo (Fernandes et al. 1988, 1997; Gonçalves-Alvim and Fernandes 2001; Maia 2001; Urso-Guimarães et al. 2003; Maia and Fernandes 2004; Oliveira and Maia 2005; UrsoGuimarães and Scareli-Santos 2006; Maia et al. 2008; Carneiro et al. 2009; Maia and Oliveira 2010; Saito and Urso-Guimarães 2012; Maia 2013), and less frequently in the states of Espírito Santo (Bregonci et al. 2010; Maia et al. in press) and Pernambuco (Fernandes et al. 2009; Santos et al. 2011a, b; Santos et al. 2012). Nevertheless, the taxonomic knowledge of the galling insects are still incipient, as the majority of the records have been presented in suprageneric categories.

Guapira opposita (Vell.) Reitz (Nyctaginaceae), commonly knew as "maria-faceira", "maria-mole" or lourobranco", is a native plant, with occurrence in four Brazilian biomes: Amazonia, Caatinga, Cerrado, and Atlantic Forest (ombrophilous dense forest, seasonal semideciduous forest, restinga, and mangrove). It is widespread, being recorded in the North (Amapá, Pará, Amazonas, Tocantins), Northeast (Maranhão, Ceará, Paraíba, Pernambuco, Bahia, Alagoas), Center-West (Goiás, Distrito Federal, Mato Grosso do Sul), Southeast (Minas Gerais, Espírito Santo, São Paulo, Rio de Janeiro), and South (Paraná, Santa Catarina, Rio Grande do Sul) regions of Brazil (Sá 2010).

Six species of Cecidomyiidae (Diptera) are associated with this plant: Bruggmannia acaudata Maia, 2004; B. elongata Maia \& Couri, 1993; B. robusta Maia \& Couri, 1993; Pisphondylia brasiliensis Couri \& Maia 1992; and Proasphondylia guapirae Maia, 1993; and Pr. formosa Maia, 1993. Each one induces a specific gall with unique morphological characteristics (Maia 2013). The main purpose of the present work is to contribute to the knowledge of the geographic distribution of the gall midges associated with Guapira opposita. Little is known about the geographical distribution of these species, being the previous records largely restricted to the Southeast region. For the first time, Bruggmannia acaudata, B. elongata, B. robusta, and Pi. brasiliensis are recorded in the State of Bahia.
The coastal vegetation of Porto Seguro (Bahia, Northeast region, Brazil) was surveyed from Arraial da Ajuda $\left(16^{\circ} 28^{\prime} 26^{\prime \prime} \mathrm{S}, 39^{\circ} 08^{\prime} 56^{\prime \prime} \mathrm{W}\right)$ to Trancoso $\left(16^{\circ} 32^{\prime} 27^{\prime \prime}\right.$ S, $39^{\circ} 06^{\prime} 28^{\prime \prime} \mathrm{W}$ ), in September of 2013 for $8 \mathrm{hr}$ by two people. Individuals of Guapira opposita were investigated for insect galls. The gall morphotypes were photographed in field with a digital camera and samples of each morphotype were collected and dissected. Other samples were dried, pressed and deposited in the galls collection of the Museu Nacional, Universidade Federal do Rio de Janeiro. The gall midges were identified based on gall and larva morphology, according to the descriptions of Maia (2001).

Four gall morphotypes were found on G. opposita, three in leaves and one in buds. The leaf galls were induced by three distinct species of Bruggmannia Tavares, 1906 (Diptera, Cecidomyiidae): B. acaudata (conical, glabrous, green or reddish gall; Figure 1), B. elongata (discoid, glabrous, green or reddish gall; Figure 2), and B. robusta (globoid, hairy, green, yellow or reddish gall; Figure 3). The bud gall was induced by Pi. brasiliensis (rosette, green, glabrous gall, Figure 4).

The previous records of B. acaudata, B. elongata and $B$. robusta include several restinga areas of the State of Rio de Janeiro (Ilha Grande in Angra dos Reis, Mangaratiba, Maricá, Carapebus, and Jurubatiba), and ombrophilous forest areas of Santa Teresa (Espírito Santo). B. elongata and $B$. robusta occur also em Arraial do Cabo (RJ) and Bertioga (SP). Comparatively, Pi. brasiliensis has the broadest geographic distribution, occurring in Rio Grande do Sul (Porto Alegre), São Paulo (Bertioga), Rio de Janeiro (Maricá and Jurubatiba), Espírito Santo (Santa Teresa), and Minas Gerais (Brumadinho) (Maia 2001; Monteiro et al. 2004; Maia et al. 2008; Maia and Oliveira 2010; Maia et al. 2010; Rodrigues et al. 2014; Maia et al in press).

Based on these data, we can realize that the geographic distribution of these gall midge species was restricted to the Southeast and South regions of Brazil. So, the occurrence in Bahia expands their distribution to the Northeast region. As the host plant species is wide-spread in Brazil, the gallers 

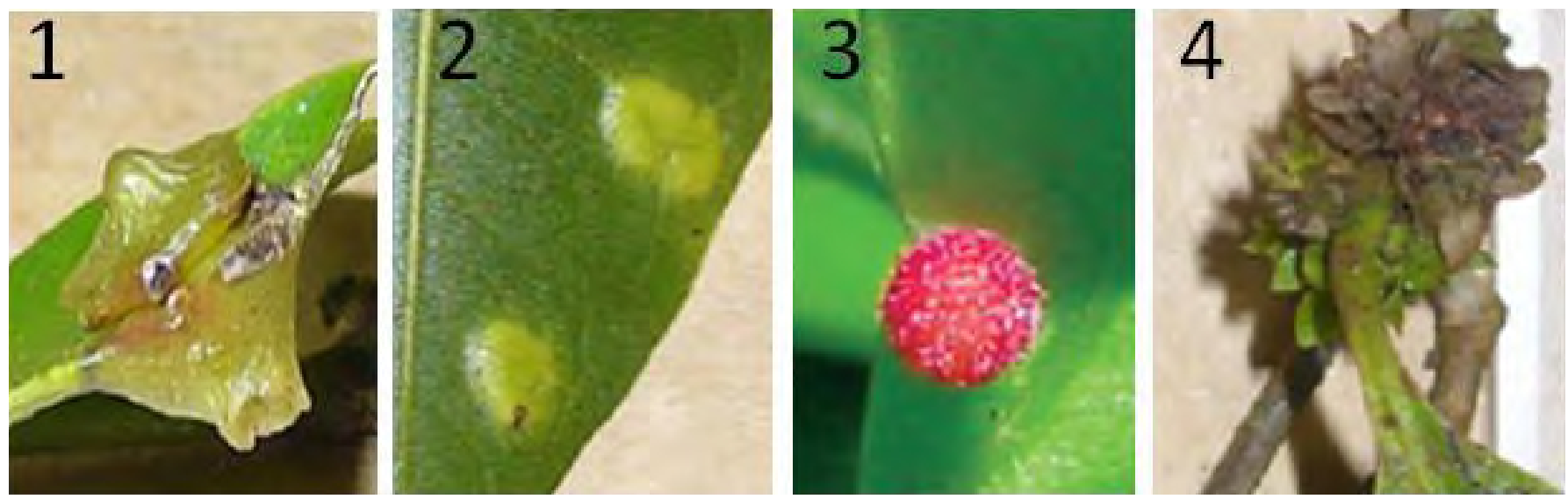

FiguRES 1-4. Galls of Cecidomyiidae (Diptera) on Guapira opposita (Nyctaginaceae). 1: Galls of Bruggmannia acaudata. 2: Gall of B. elongata. 3: Gall of B. robusta. 4: gall of Pisphondylia brasiliensis.

associated with it can also have a wider distribution, e.g., Santos et al. (2012) in an inventory of gall inducing insects and their host plants in the Atlantic forest of Pernambuco, they found nine morphospecies of galling insect to this host plant. Although G. opposita has been recorded in four biomes, Amazonia, Caatinga, Cerrado, and Atlantic Forest, the current distribution of the galling species includes only cerrado (rupestrian fields) and Atlantic forest (restinga, ombrophilous forest and deciduous seasonal forest) areas. As few insect galls inventories have been developed in Amazonia and Caatinga, collections in these biomes are necessary to understand the pattern of distribution of the studied species.

ACKNOWLEDGements: To Dr. Bernardo Mascarenhas (Museu Nacional, Universidade Federal do Rio de Janeiro) for field assistance and to $\mathrm{CNPq}$ for financial support.

\section{LITERATURE Cited}

Bregonci, J.M., P.V. Polycarpo and V.C. Maia. 2010. Galhas de insetos do Parque Estadual Paulo César Vinha (Guarapari, ES, Brasil). Biota Neotropica 10(1): 1-10 (doi: 10.1590/S1676-06032010000100023).

Carneiro, M.A.A., R.A.X. Borges, A.P.A. Araújo and G.W. Fernandes. 2009. Insetos indutores de galhas da porção sul da Cadeia do Espinhaço, Minas Gerais, Brasil. Revista Brasileira de Entomologia 53(4): 570592 (doi: 10.1590/S0085-56262009000400007).

Fernandes G.W., E. Tameirão Neto and R.P. Martins. 1988. Ocorrência e caracterização de galhas entomógenas na vegetação do campus Pampulha da Universidade Federal de Minas Gerais. Revista Brasileira de Zoologia 5(1): 11-29 (doi: 10.1590/S0101-81751988000100002).

Fernandes G.W., R.C. Araújo, S.C. Araújo, J.A. Lombardi, A.S. de Paula, R. Loyola Jr. and T.G. Cornelissen. 1997. Insect galls from savanna and rocky fields of Jequitinhonha Valley, Minas Gerais, Brazil. Naturalia 22: 221-244.

Fernandes S.P.C., B.P. Castelo-Branco, F.A. de Albuquerque, A.L.N. Ferreira, A.B. Brito-Ramos, D.V.V. Braga and J. Almeida-Cortez. 2009. Galhas entomógenas em um fragmento urbano de Mata Atlântica no centro de endemismo de Pernambuco. Revista Brasileira de Biociências 7(3): 240-244 (http://www.ufrgs.br/seerbio/ojs/index.php/rbb/ article/view/1106).

Gonçalves-Alvim S. and G.W. Fernandes. 2001. Comunidades de insetos galhadores (Insecta) em diferentes fisionomias do cerrado em Minas Gerais, Brasil. Revista Brasileira de Zoologia 18(Suppl. 1): 289-305 (doi: 10.1590/S0101-81752001000500025).

Maia, V.C., L.J.T. Cardoso and J.M.A. Braga. 2014. Insect galls from Atlantic Forest areas of Santa Teresa, Espírito Santo, Brazil: Characterization and occurrence. Boletim do Museu de Biologia Mello Leitão (Nova Série) 33: 47-129 (http://www.boletimmbml.net/boletim/index.php/boletim $\mathrm{mbml} /$ article/view/16).

Maia, V.C. 2001. The gall midges (Diptera, Cecidomyiidae) from three restingas of Rio de Janeiro State, Brazil. Revista Brasileira de Zoologia 18(2): 583-629 (doi: 10.1590/S0101-81752001000200028).

Maia, V.C. 2013. Galhas de insetos em restingas da região sudeste do Brasil com novos registros. Biota Neotropica 13(1): 183-209 (doi: 10.1590/S1676-06032013000100021).

Maia, V.C. and G.W. Fernandes. 2004. Insect galls from Serra de São José (Tiradentes, MG, Brazil). Brazilian Journal of Biology 64(3A): 423445 (doi: 10.1590/S1519-69842004000300007).
Maia, V.C., M.A.G. Magenta and S.E. Martins. 2008. Ocorrência e caracterização de galhas de insetos em áreas de restinga de Bertioga (São Paulo, Brasil). Biota Neotropica 8(1): 167-197 (doi: 10.1590/ S1676-06032008000100020).

Maia, V.C. and J.C. Oiveira. 2010. Galhas de insetos da Reserva Biológica Estadual da Praia do Sul (Ilha Grande, Angra dos Reis, RJ). Biota Neotropica 10(4): 227-238.

Maia, VC., G.B. Fleury, GLG. Soares and R.M.S. Isaias. 2010. Description of the female, pupa and gall of Pisphondylia brasiliensis Couri and Maia, 1992 (Diptera: Cecidomyiidae, Schizomyiina) with new records. Brazilian Journal of Biology 70(4): 1059-1063 (doi: 10.1590/S151969842010000500021).

Maia, V.C., A.R. Rodrigues, S.H.S. Ascendino and M. Boggi. In press. The insect gall collection of the Museu Nacional/Universidade Federal do Rio de Janeiro: biome cerrado, rupestrian fields. Brazilian Journal of Biology.

Monteiro, R.F., R.A.M. Oda, K.L. Narahara and P.A.L. Constantino. 2004. Galhas: Diversidade, Especificidade e Distribuição; pp. 127-141, in: C.F.D. Rocha, F.A. Esteves and F.R. Scarano (ed.). Pesquisa de Longa Duração na Restinga de Jurubatiba: Ecologia, História Natural e Conservação. São Carlos: RiMa Editora.

Oliveira, J.C. and V.C. Maia. 2005. Ocorrência e caracterização de galhas de insetos na restinga de Grumari (Rio de Janeiro, RJ, Brasil). Arquivos do Museu Nacional 63(4): 669-676.

Rodrigues, A.R., V.C. Maia and M.S. Couri. 2014. Insect galls of restinga areas of Ilha da Marambaia, Rio de Janeiro, Brazil. Revista Brasileira de Entomologia 58: 173-197 (doi: 10.1590/S008556262014000200010).

Sá, C.F.C. 2010. Nyctaginaceae in Lista de Espécies da Flora do Brasil, Jardim Botânico do Rio de Janeiro. Accessible at http://floradobrasil. jbrj.gov.br/2010/FB010913. Captured on November 2013.

Saito, V.S. and M.V. Urso-Guimarães. 2012. Characterization of galls, insect galls and associated fauna of Ecological Station of Jataí (Luiz Antônio, SP). Biota Neotropica 12(3): 1-9 (doi: 10.1590/S008556262014000200010).

Santos J.C., J.S. Almeida-Cortez and G.W. Fernandes. 2011a. Diversity of gall-inducing insects in the high altitude wetland forests in Pernambuco, Northeastern Brazil. Brazilian Journal of Biology 71: 47-56 (doi: 10.1590/S1519-69842011000100008)

Santos, J.C., J.S. Almeida-Cortez and G.W. Fernandes. 2011b. Richness of gall-inducing insects in the tropical dry forest (caatinga) of Pernambuco. Revista Brasileira de Entomologia 55(1): 45-54.

Santos J.C., J.S. Almeida-Cortez and G.W. Fernandes. 2012. Gallinducing insects from Atlantic forest of Pernambuco, Northeastern Brazil. Biota Neotropica 12(3): 197-213 (doi: 10.1590/S151969842011000100008).

Urso-Guimarães, M.V. and C. Scareli-Santos. 2006. Galls and gall makers in plants from the Pé-de-Gigante cerrado reserva, Santa Rita do Passa Quatro, SP, Brazil. Brazilian Journal of Biology 66(1B): 357-369 (doi: 10.1590/S1519-69842006000200018).

Urso-Guimarães, M.V., C. Scareli-Santos and A.C. Bonifácio-Silva. 2003. Occurrence and characterization of entomogenous galls in plants from natural vegetation areas in Delfinópolis, MG, Brazil. Brazilian Journal of Biology 63(4): 705-715 (doi: 10.1590/S151969842003000400018).

RECEIVED: October 2013

ACCEPTED: July 2014

Published ONLINE: September 2014

EDITORIAL RESPONSIBILITY: Marco Silva Gottschalk 